Özge Tecimer, Dolunay Akgül Barış

Bolu Abant İzet Baysal University, Bolu-Turkey oztecimer91@gmail.com; dolunayakgul@hotmail.com

\begin{tabular}{l}
\begin{tabular}{l|l|l|} 
DOI & http: $/ / \mathrm{dx} . \mathrm{doi}$. org/10.12739/NWSA.2018.13.4.D0220 \\
\hline ORCID ID & $0000-0002-8421-1782$ & \\
CORRESPONDING AUTHOR & Özge Tecimer
\end{tabular} \\
\hline
\end{tabular}

\title{
İLK VE ORTAOKULLARDA BLOK FLÜT EĞİTIMİ İÇİN EĞİTSEL VİDEO DERS MATERYALI HAZIRLAMA
}

öz

Bu araştırmada, ilk ve ortaokullarda, müzik derslerinde sınıf öğretmenlerinin, müzik öğretmenlerinin ve öğrencilerin Blok Flüt eğitiminde kullanabilmeleri amacıyla hazırlanan eğitim videolarının, nasıl hazırlanacağı ve hazırlamadaki aşamaların tanıtılması amaçlanmaktadır. Günümüz çocuklarının kendi hayal dünyaları düşünülerek ve Blok flütü de daha fazla sevmeleri ve benimsemeleri için eğitsel video materyalinin görsel materyaller ve animasyonlardan oluşturulması tasarlanmıştır. Böylece çocukların, Blok flütü sevip çalmak için daha istekli olacağı ve doğru bir şekilde kullanacakları düşünülmektedir. Araştırmanın evrenini, Müzik Öğretim Programı (2005) 4. ve 5. Sınıf çalgı eğitimine yönelik kazanımlar oluşturmaktadır. Hazırlanan materyallerin oluşturulabilmesi için nitel araştırma yöntemlerinden eylem araştırması deseni kullanılmış, verilerin toplanmasında görüşme türlerinden yapılandırılmış görüşme formu tekniği kullanılmıştır. Araştırmada görüşme tekniği ile elde edilen veriler nitel veri analizi yöntemlerinden "İçerik Analizi" yöntemiyle çözümlenmistir.

Anahtar Kelimeler: Blok Flüt, Teknoloji Destekli Eğitim, Video Destekli Eğitim, Bilgisayar Destekli Eğitim, Animasyon Destekli Eğitim

\section{PREPARING EDUCATIONAL VIDEO MATERIAL FOR RECORDER TRAINING IN THE PRIMARY AND SECONDRY SCHOOLS}

\section{ABSTRACT}

In this study, it is aimed that to present to the class teachers, music teachers and students in primary and secondary schools how the videos which prepared to be able to use at Block Flute training, should be prepared and introduced the steps of preparation. By being considered about the imagination worlds of today's children, it is designed to create educational video material from visual materials and animations to make the children love and embrace of the Block Flute more. Thus, it is thought that children will be willing to love and play the Block Flute and use it correctly. The universe of the research is composed of the achievements for the 4 th and 5 th grade musical education of the Music Education Program (2005). For composing the prepared materials, the action research pattern from the qualitative research technique and interview form technique as the interviewing tool were used. The data obtained with the interviewing technique in the research were analyzed using the "Content Analysis Method" as the qualitative data analysis method.

Keywords: Block Flute, Technology Assisted Education, Video Assisted Education, Computer Assisted Education, Animation Assisted Education

How to Cite:

Tecimer, G. ve Akgül Barış, D., (2018). İlk ve Ortaokullarda Blok Flüt Eğitimi İçin Eğitsel Video Ders Materyali Hazırlama, Fine Arts (NWSAFA), $13(4): 117-132$, DOI: $10.12739 /$ NWSA.2018.13.4.D0220. 


\section{GİRIŞ (INTRODUCTION)}

Bilim ve teknoloji alanında çağın gerektirdiği hızlı değişimler Günümüzde artık eğitim alanında da teknolojinin aktif kullanımını gündeme getirmektedir. Teknoloji çağının çocukları artık akılıı tahtaların da sınıflarda kara tahtanın yerini almasıyla bilgiye daha kolay ulaşır hale gelmişlerdir. Çağdaş eğitimin bir gereksinimi olan teknoloji, toplumlarında farkındalığı ile artık daha çok tercih edilen ve sürekli gelişmekte olan bir unsur haline gelmiştir. Eğitimde karşılaşılan en önemli sorunlardan birisi de öğrencilerin öğrendikleri konuları çok çabuk unutmaları ve konuların tekrar edilmesi gerekliliğidir. Konuların derste özetlenmesi genel olarak bilinen bir pedagojik ilkedir. Ancak müfredat programının yoğunluğu çoğu zaman derslerin bire bir tekrarlanmasına olanak tanımamaktadır. Buna bir de konuya ilişkin öğrenme düzeyleri yüksek olan öğrencilerin oluşturacağı problemleri eklersek öğrencilerin ders dışında bireysel olarak tekrar ve alıştırma yapabilecekleri etkinlikler geliştirme gerekliliği gündeme gelmektedir. Bu kapsamda kullanllan materyallerden biri de eğitsel videolardır. Öğretmenler kendileri eğitim videoları çekebilirler, anlattıkları dersleri, yaptıkları etkinlikleri, dijital kameralar yardımı ile çekip öğrencileri ile paylaşabilirler (http://materyaltasarimi.weebly.com/6etkinlike287itsel-video-

haz305rlama.html).

İlk ve orta öğretim kurumlarında müzik derslerinde önceden teknolojik cihazlar sık kullanılmaz ve bilinmezken günümüzde artık fazlasıyla rağbet görmeye başlamıştır. Müzik eğitiminde de diğer alan derslerinde olduğu gibi görsel materyallere önem verilerek bir yardımcı kaynak düşüncesiyle teknolojik cihazlardan yararlanılmıştır. Öğrenciler görsel materyallerin kullanımı sayesinde müzik derslerinde öğrendikleri bilgileri daha kolay öğrenme şansını bulmuşlardır. İlkokullarda müzik derslerine sınıf öğretmenleri girmektedir. Öğretmenler özellikle müzik derslerinde çalgı eğitimi için programda yer alan Blok flütü tercih etmekte fakat çoğu zaman nasıl bir yol izlemeleri gerektiği konusunda ders kitaplarında yer alan bilgilerin dışına çıkamamaktadırlar. Ayrıca bu alan ile ilgili görsel materyaller özellikle video ders materyallerinin fazla bulunmadığı, yardımcı kaynak olarak doğru bir şekilde kullanacakları video ders materyalleri sınırlı olduğu da söylenebilir. Bu amaçla, ilk ve ortaokullarda blok flüt eğitimine yönelik bir eğitsel video ders materyalleri serisi hazırlama düşüncesi doğmuş ve bu hazırlanacak eğitsel video ders materyallerinin, müzik öğretmenleri için de dersin daha zevkli ve kalıcı işlenmesine olanak sağlayıcı pekiştireç olarak kullanabilecekleri yardımcı bir kaynak olacağı düşünülmüştür. Bunun yanı sıra öğrenciler de bu video destekli ders materyallerini ders dışında da aktif bir şekilde kullanıp öğrendikleri konuyu kendi kendilerine pekiştirme olanağı bulabilirler. Bu amaçlar çerçevesinde araştırmanın problem cümlesi şu şekilde ifade edilmektedir.

\section{2. ÇALIŞMANIN ÖNEMI (RESEARCH SIGNIFICANCE)}

Araştırma, günümüz çocukları için geleneksel müzik dersi işleniş biçimini renklendirebilecek, video ders materyallerinin öğretmenler ya da bu konuya ilgi duyanlar tarafindan nasıl yapılabileceğini açıklayıcı bir çalışma olması bakımından önemli görülmektedir. Ayrıca, çocukların kendi hayal dünyaları düşünülerek ve Blok flütü de daha fazla sevmeleri ve benimsemeleri için video ders materyalinin görsel materyaller ve animasyonlardan oluşturulması uygun bulunmuştur. İlkokullarda sınıf öğretmenlerinin müzik dersine yönelik çalgı eğitimi boyutunda kaynak sıkıntısı olduğu düşünülerek, Bu nedenle bu araştırma, sonucunda oluşturulacak örnek eğitsel video materyali sayesinde, hem sınıf öğretmenlerine hem de müzik öğretmenlerine örnek 
bir kaynak teşkil etmesi ve bundan sonra yapılacak bu ve buna benzer konulardaki çalışmalara yol göstermesi açısından da önemli görülmektedir.

\section{3. ÇALIŞMANIN AMACI (RESEARCH PURPOSE)}

Bu araştırmada, ilk ve ortaokullarda okuyan öğrencilerin, sınıf öğretmenlerinin ve müzik öğretmenlerinin Blok Flüt eğitiminde kullanabilmesi amacıyla bir video ders materyali hazırlamak ve bu materyali hazırlamak için geçilen aşamaların ortaya koyulması amaçlanmaktadır. Ayrıca, diğer bir amacı d, teknoloji çağını yaşadığımız günümüzde Blok flüt eğitimi için, kullanışlı bir eğitim materyali oluşturmak ve bundan sonraki nesiller içinde yararlı bir eğitim aracı olarak kullanılabilirliğine zemin hazırlamaktır.

\subsection{Problem Cümlesi (Problem Clause)}

- İlk ve Ortaokullarda Blok Flüt Eğitimi için eğitsel video ders materyali nasıl hazırlanır?

\subsection{Alt Problemler (Sub-Problems)}

- Eğitsel video ders materyalleri hazırlanırken izlenilen aşamalar konusunda uzman görüşleri nelerdir?

- Eğitsel Video ders materyallerinin özelliklerine yönelik uzman görüşleri nelerdir?

- (Materyalin kullanıldığı eğitim türleri, hedef kitle, maddi boyutu, kullanımdaki avantaj ve dezavantajları)

- Uzman görüşleri doğrultusunda i̇lk ve ortaokullarda blok flüt eğitimine yönelik Eğitsel video ders materyalinin oluşturulması nasıl gerçekleşmektedir?

\subsection{Sınırlılıklar (Limitations)}

- Eğitsel video materyali hazırlama konusunda alanında uzman kişilerin görüşleriyle.

- Müzik öğretim programı (2005), 4. ve 5. Sınıf çalgı eğitimine yönelik kazanımlar ile sınırlandırılmıştır.

\section{KAVRAMSAL ÇERÇEVE (CONCEPTUAL FRAME)}

\subsection{Eğitim Teknolojisi (Educational Technology)}

"Eğitim" ve "Teknoloji" olarak bu iki olguyu açıklamak gerekirse; Ertürk'e göre (1972:12) "Eğitim, bireyde kendi yaşantısı yolu ile kasıtlı ve istendik davranış değişikliği meydana getirme sürecidir." Teknoloji sözcüğü ise incelendiğinde, kapsamı içerisinde makineler, işlemler, yöntemler, süreçler, sistemler, yönetim ve kontrol mekanizmaları gibi çeşitli öğelerin yer aldığı görülmektedir. o halde teknoloji bu öğelerin belirli bir düzende bir araya getirilmesiyle oluşan ve bilim ile uygulama arasında köprü görevi yapan bir disiplin olarak tanlmlanabilir (Alkan, 1997:17). Alkan (1997:12)'e göre Teknoloji, insanoğlunun eğitim yoluyla kazandığı bilgi ve becerilerinden daha etken, daha verimli biçimde yararlanabilmesinde, onları daha sistemli ve bilinçli olarak uygulayabilmesinde yardımcı olmuştur. Böylece eğitim ve teknoloji insanoğlunun mükemmelleştirilmesi, kültürlenmesi ve geliştirilmesi, doğaya ve çevresine karşı etken ve nüfuzlu, egemen bir unsur haline gelmesine sebebiyet vermiştir. Bilgisayar ortamına doğan yeni nesil için aldıkları eğitimin teknoloji ile desteklenmesi kaçınılmaz bir ihtiyaçtır. Görmüş ve almış oldukları eğitim bu dönemde teknolojik cihazlarla daha verimli ve öğretici bir eğitim sistemi olarak karşımıza çıkmaktadır. Öğretmen-öğrenci etkileşimli eğitim artık bu yeni nesil için yavan, sıradan ve sıkıcı bir hal almıştır. O halde 
eğitim teknolojisi ile oluşturulacak; bilimsel, çağdaş, ileri düzeyde olan ekipmanlarla eğitim daha kaliteli ve yeterli hale gelecektir. Diel, 1978, (Çev. Demiray, Ed. Tekin, 1988:127)'e göre, Eğitim teknolojisi, araç-gereç ve teknolojinin öğrenme/öğretme sürecine uyarlanmasıyla, ders teknolojisinin değişik bir nitelik kazanmasıdır. Değişen bu yeni durum, eğitim araçları, öğrenme sistemleri ve yapılacak olan düzenlemelerin yeni yaklaşımlarla dile getirilişi, başka bir anlatımla yeni bir düşünme biçimidir.

\section{2. Öğretim Teknolojisi (Instructional Technology)}

"Öğretim Teknolojisi" de eğitim teknolojisinin bir parçasıdır. Ergin, (1995:6)'e göre, Öğretim Teknolojisi; "özel amaçların gerçekleştirilmesinde etkili öğrenme sağlamak için iletişim ve öğrenmeyle ilgili araştırmalardan hareketle, insan gücü ve insan gücü dışı kaynaklar kullanılarak öğretme-öğrenme sürecinin tasarlanması, yürütülmesi ve değerlendirilmesinde sistematik bir yaklaşım" dır. Öğretim Teknolojisinin öğrenciye kazandırdığı davranış değişikliği, öğretimde yeniliklerin olması ve öğrencilerin bu eğitim-öğretim sistemiyle kendilerini bulmaları doğrudan orantılıdır. öğretim Teknolojisinde materyal kullanımı da önemli bir yer tutar. Öğrenciler materyaller sayesinde derslerdeki işlenen konuları daha rahat anlarlar. Öğrencilerin bireysel farklılıklarını da göz önünde bulundurarak önemli bir öğretim yöntemi bu materyaller sayesinde geliştirilmiştir.

\section{3. Öğretim Materyallerinin Eğitim-Öğretime Sağladığı Yararlar (Teaching Materials' Benefits to Education)}

- Öğrenmeyi kalıcı hale getirir.

- Öğrencilerin ilgisini çeker.

- Öğrenmeyi güçlendirir.

- Anlamın gelişmesi ve anlatım kolaylığı sağlar.

- Öğretimde zaman kazandırır.

- Öğrenmede uyarıcı etki yapar.

- Düşüncenin devamlılığını sağlar.

- Öğretim süreçlerini güçlendirir ve etkin kılar.

- Sözcük gelişimine katkı sağlar (http://botemateryal.blogspot. com.tr/p/egitim-ogretime-sagladıg-yararlar_2.html).

\subsection{Eğitim-Öğretim Teknolojisinde Video Ders Materyalleri (Video Course Materials in Educational Technology)}

- Video ile Anlatım: Eğitim Öğretim teknolojisinde en yaygın olarak kullanılan öğretim metotlarından birisi video destekli öğretimdir. Video ile anlatımda öğretmen kendini videoya çekmiş, bu şekilde dersi işlemiştir. Video destekli öğretimin avantajı buradan dersi takip eden öğrencinin kendisini sınıf ortamında hissetmesinin sağlanması ve konuyu istediği zaman durdurup tekrar izleyebilmesidir. Bu tür yaklaşımların dışında günümüzde eğitsel videolar eğitimin her alanında sıkça kullanılır olmuştur (Savaş ve Arıcı, 2009:3).

- Animasyon ile Anlatım: Bu ders anlatım türünde konular slayt şeklinde ünitelere ayrılmıştır. Konu anlatımını güçlendirmek amacı ile çeşitli flash animasyonlar kullanılmıştır. Yapılan uygulama ile, öğrencinin hazırlanan senaryolarının içerisinde dolaşarak öğretilmesi hedeflenen bilgi, kavram ve olguları keşfetmesi hedeflenmektedir (Savaş ve Arıcı, 2009:3). 

araştırma, yaratıcı yazı yazma, üretim gibi birçok işlemden oluşur. Bu nedenle bir video filmi üretilmeden önce ders öğretmeninin kendi kendine şu soruları sorup olumlu yanıt almasında yarar vardır: öğrencilerin gereksinimleri nelerdir ve öğrenciler bu dersten ne bekliyorlar? Öğrencilerin giriş davranışları, bilişsel tarzları ve altyapıları konusunda ne biliyorum? Öğretimde öğrencileri nasıl güdülerim? Öğrencilere uygun ve uygulanır bir öğretim nasıl oluştururum? Öğrenmede öğrencilere nasıl rehberlik edebilir ve öğrencileri destekleyebilirim? Öğrencilerin nitelikli öğrenme beklentilerini nasıl temin edebilirim? Bu filmden beklentilerim nelerdir? Bu film hedeflerime yeterince ulaşılacak mı? Bu filmin öğrenmeyi etkileyen olumlu ve olumsuz yanları nelerdir? Bu filmin sınırlılıklarını en aza indirirken, filmi daha iyi nasıl kullanırım? Video ders materyali için sırasıyla izlenilmesi gereken başlıca dokuz aşama vardır. Bunlar; Konu Seçimi, Hedef, Konu, Resimli Öykü, Değerlendirme ve Geliştirme, Senaryo, Üretime Hazırlık, Kayıt, Kurgu (Kaya, 2005:191)

\subsection{Eğitsel Video Materyallerinin Yararları ve Sınırlılıkları (Benefits and Limitations of Educational Video Materials)}

Video kullanmanın öğretim sürecine birçok katkısı vardır. Bu katkılar aşağıdaki gibi sıralanabilir:

- Görme ve işitme duyusuna ayni anda etki eder.

- Hareket, renk ve ses boyutlarıyla öğrenmeyi kolaylaştırır.

- Özel görüntü ve çekim tekniklerini kullanabilme olanağı sağlar.

- Bilginin sunuluşunda ve akışında düzen sağlar.

- Istenilen sayıda tekrar yapabilme olanağı sağlar (Orhan ve Akkoyunlu, 1999:137).

Her alandaki modellerde olduğu gibi Bilgisayar Destekli modellerinin de sınırlılıkları vardır. Araştırmacılara göre BDE' in en büyük sınırlılığı öğrenci-eğitimci ilişkisinin kurulamamış olmasından kaynaklandığı sonucudur. Öğrencilerin derse katkısı, sevgisi ve de ilgisinin en büyük faktörünün eğitimci olduğu tüm araştırmacılar tarafından kabul edilmiştir (Dinçer, 2006).

\subsection{Video Ders Materyali Hazırlama Süreci (Video Course Material Preparation Process)}

Video Ders Materyali Hazırlama Süreci bir ekip çalışmasını gerektirmektedir. Kaya (2005:168)'ya göre yapılacak işlemler tasarım ekibi olarak adlandırılabilecek bir ekip tarafından yürütülür. Tasarım ekibinde şu görevliler yer alır: Proje Yöneticisi, Yapımcı-yönetmen, Öğretim Süreçleri Tasarımcısı, Alan Uzmanı, Senaryo Yazarı, Eğitim Psikoloğu, Grafik Uzmanı ve Video Grafik Uzmanı, Ses Uzmanı.

Yapım Öncesi İşlemler Şunlardır:

- Gereksinim çözümlemesi.

- Hedeflerin belirlenmesi.

- Stratejilerin belirlenmesi.

- Ayrıntılı öykünün hazırlanması.

- Senaryonun resimli öyküsünün hazırlanması

- Dersin senaryosunun yazımı.

Gerekli gereksinimlerin çözümlemesi, hedefler ile stratejilerin belirlenmesi ve ayrıntılı öykünün hazırlanması işleminin ardından senaryonun resimli öyküsü hazırlanır (Kaya, 2005:169). 


\subsection{Genel Müzik Eğitiminde Blok Flüt Eğitimi}

\section{(Block Flute Training in General Music Education)}

Genel müzik eğitiminde çalgı eğitiminin yeri ayrıdır. Çalgı eğitimi, müzik eğitiminin önemli bir unsurudur. Öğrenciler temel müzik eğitiminde öğrenmiş oldukları nota değerlerini, tartımları, ezgileri çalgılarıyla seslendirerek çalıştıkları parçaları daha rahat öğrenebileceklerdir. Okullardaki müzik derslerinde kullanılan çalgılar; çocukların müzikteki duyuşsal gelişimlerini, şarkı söylemedeki beraberliğini çalgı çalarak da pekiştirebileceğini göstermektedir. Bu sayede çocuklar birlikte çalgı çalarak toplu çalışılan parçalara daha özverili ve daha birbirlerini dinleyerek çalışacaklardır. Müzik dersleri içerisinde önemli bir yere sahip olan çalgı eğitimi, öğrencinin kendisini ifade edebileceği, sesleri somutlaştırabileceği, fiziksel özelliklerini keşfedebileceği, müzikalitesini geliştirebileceği, kısacası müzik yapmayı öğrenebileceği, önemli bir boyutu oluşturmaktadır. Çalgı eğitimi yolu ile "Çocuklar sınıf içerisinde hem çalgının gerektirdiği temel davranış ve becerileri öğrenirken, hem de birlikte müzik yapmanın keyfine varırlar" (Akgül Barış, 2007:1-12). Bu nedenle çalgı eğitimine özellikle ilkokullardaki müzik derslerinde en az nota öğretimi ve şarkı eğitimi kadar önem verilmelidir. Genel müzik eğitimi verilen ilkokul ve ortaokullarda çalgı eğitiminde genellikle Blok flüt kullanılmaktadır. Blok flüt, günümüzde öğrenilmesinin kolay olması, öğrencilerin çalabilmesi için zor bir enstrüman olmaması, kolaylıkla taşınabilir olması, çalarken hafif bir çalgı olduğu için çalanı yormaması, çalarken düz tutulduğu için anatomik yapıdan da çalgıyı çalmanın çalıcıya rahatsızlık vermemesi, maddi açıdan uygun olması, çalınabilecek birçok repertuarının olması nedeniyle okullardaki müzik eğitimi ve özellikle çalgı eğitiminde tercih sebebi olmuştur.

\section{YÖNTEM (METHOD)}

\subsection{Araştırma Modeli (Research Model)}

İlkokullarda Blok Flüt Eğitimi İçin Eğitsel Video Ders Materyali Hazırlama konulu bu araştırmada, nitel araştırma yöntemlerinden eylem araştırması deseni kullanılmıştır. Eylem araştırması süreç odaklıdır. Belli bir sürecin kendi ortamı içinde uzun bir süre çalışılması ve odaklanılan soruna ilişkin veri toplanması söz konusudur. Ayrıca, eylem araştırmalarında esnek bir yaklaşım söz konusudur. Araştırmacının veriye yakın olması, süreci yakından tanıması ve yaşaması önemlidir. Nitel araştırmada vurgulanan "araştırmacının katılımcı rolü ve aynı zamanda veri toplama aracı olması" durumu bu yaklaşımda tam anlamıyla kendini göstermiştir (Yıldırım ve Şimşek, 2013:84). Ayrıca araştırmada doküman inceleme yöntemi de kullanılmıştır. Bu yöntem sayesinde araştırmanın içeriği derinleştirilmiştir.

\subsection{Evren ve Örneklem (Universe and Sample)}

Araştırmanın evrenini, Müzik Öğretim Programı (2005) 4. ve 5. Sınıf çalgı eğitimine yönelik kazanımlar oluşturmaktadır. Araştırmada, Eğitim Teknolojileri Genel Müdürlüğü'nden 2 alan uzmanı ve BAİBÜ'den Bilgisayar Teknolojileri Bölümünden 2 öğretim elemanı ve Resim-İs Anabilim Dalı Grafik dersi öğretim elemanlarından 2 olmak üzere toplamda 6 uzman görüşü alınmıştır.

\subsection{Verilerin Toplanması (Data Collection)}

Araştırmanın alt problemlerinin çözümü için gerekli veriler, "İlk ve Ortaokullarda Blok flüt eğitimi için eğitsel video materyali hazırlama" konusuna ilişkin hazırlanan görüşme formu ile toplanmıştır. Görüşme formunda açık uçlu sorulara yer verilmiştir. Görüşme formu 
uzman görüşleri doğrultusunda hazırlanarak, pilot uygulamalardan sonra son şekli verilmiş ve gerekli izinler alındıktan sonra uygulanmıştır.

\subsection{Verilerin Çözümlenmesi (Analysis of Data)}

Araştırmada görüşme yöntemiyle elde edilen veriler nitel veri analizi yöntemlerinden "İçerik Analizi" yöntemiyle çözümlenmiştir. Görüşme esnasında kayıt yoluyla elde edilen veriler öncelikle yazıya dökülmüştür. Görüşme verileri nesnel yaklaşımla düzenlenmiş, anlamlı cümlelere dönüştürülmüştür. Bir sonraki aşamada veriler kodlanmıştır. İkinci aşamada temalar bulunmuştur. Bu aşamadan sonra veriler, kodlara ve temalara göre düzenlenmiş ve tanımlanmıştır. Son aşamada bulgular yorumlanmıştır.

\section{BULGULAR VE YORUM (FINDINGS AND COMMENT) \\ 6.1. Birinci Alt Probleme Ait Bulgular ve Yorum (First Sub-Problem Findings and Interpretation)}

"Eğitsel video ders materyalleri hazırlanırken izlenilen aşamalar konusunda uzman görüşleri nelerdir?". Görüşme sonuçlarından elde edilen ortak görüşler çerçevesinde aşamalar şu şekilde sıralanmaktadır. A, B, C, D, E görüşmecileri aşamaları:

- Konu belirlenir

- Metin yazarı, akademisyen, alan uzmanı ile birlikte öğretim süreçleri tasarımı için bir ekip oluşturulur. Bu ekip ders materyalleri için uygun olan süre, metod, teknik, öğrenim içerik ve yapım stratejilerini belirler

- Belirlenen süre, kazanım ve metotlara uygun olacak şekilde senaryo yazılır

- Onaylanan ve tashih edilen senaryoya bağlı olarak grafik tasarım ve animasyon çizimleri yapılır

- Storyboard hazırlanışı

- Stüdyo ya da dış ortamda video çekimi yapılır

- Çekim bilgisayar ortamına aktarılır

- Uygun bir Video-Edit (Movie-Maker, vs.) ile çekimi edit edilir (düzeltmelerde, eklemelerde bulunmak) yazı ve jenerik eklenir

- Videoyu bitirilir ve kaydetmek gerekir

- Alan uzmanları ve akademik danışmanlar eşliğinde ham materyal gözlenerek eksikler ya da eklenilmesi gerekenler belirlenir

- Gerekli düzenlemeler yapıldıktan sonra videonun kurgu ve montajı yapılır

- Dijital medyaya uyarlanacak formatlarda kaydedilir

- Yazılımci tarafindan dijital medya mecralarında izlenebilecek şekilde kodlanarak yayına verilir." Şeklinde ifade etmişlerdir Ayrıca F görüşmecisi farklı olarak:

- Hedef kitlenin analizi

- Genel özellikleri (yaş, cinsiyet, vb.)

- Konu ile ilgili ön bilgileri, hazır bulunuşlukları

- $\quad \dot{I} c ̧ e r i k$ Analizi

- Konu ile ilgili kavramlar neler

- Kavramlar arası ilişkiler

- Alt konuların sıralanışı

- Kullanilacak teknolojilerin belirlenmesi ve temin edilmesi

- Ekran tasarımi veya genel olarak tasarım

- Geliştirme videonun üretimi

- Değerlendirme

- Öz değerlendirme

- Akran değerlendirme 
o Öğrenciye sunma. Şeklinde bir sıralama yapmıştır.

\section{2. İkinci Alt Probleme Ait Bulgular ve Yorumları (Findings and Comments of the Second Sub-Problem)}

"Eğitsel video ders materyallerinin özelliklerine yönelik uzman görüşleri nelerdir?". Görüşler çerçevesinde aşağıdaki sorulara yanıt aranmıstır.

"Hedef kitleye göre hazırlanan eğitsel video ders materyalleri farklılık göstermekte midir?"

Görüşmecilerin tamamı; Hedef kitleye göre hazırlanan video ders materyallerinin farklılık gösterdiği görüşünde birleşmektedirler.

\section{Örnek ifadeler:}

- C Görüşmecisi: Video içerikleri ve çekimlerin somutluğu ya da soyutluğu hedef kitleye göre farklılık gösterir. İlkokul seviyesi için daha somut çekimler ve içerikler tercih edilir. Üst seviyelere çıktıkça soyutluk seviyesi artabilir.

- D ve E Görüşmecileri: Yaş, sınıf ve özel eğitime tabi olan hedef kitlenin algı düzeyine ve bu grupların dikkat süresine göre değişmektedir. Ayrıca eğitim müfredatında belirlenen kazanım özelliklerine göre de değişmektedir. Örneğin; Okul öncesi ve ilkokul döneminde animasyon ve dijital oyunlarla eğitim-öğretim gerçekleştirilirken, lise düzeyinde reel görüntülerle gerçekleştirilebilir. Görme, işitme ya da zihinsel engellilerde de kendi özel eğitim süreçlerine göre gerçekleşmektedir.

- F Görüşmecisi: Hedef kitlenin genel özellikleri, motivasyonları, hazır bulunuşlukları, ön bilgileri önemli olduğu için hazırlanacak video da bu faktörlerden etkilenir.

Elde edilen verilerde, hedef kitleye göre hazırlanan eğitsel video ders materyalleri farklılık göstermektedir. Belirlenen yaş, sınıf ve özel eğitime tabi olan hedef kitlenin algı düzeyine göre hazırlanacak olan video ders materyalleri öğrencilerin ilgisine göre soyut veya somut çekimlerle desteklenebilir. Ayrıca hedef kitlenin genel özellikleri, motivasyonları, hazır bulunuşlukları dikkate alınmalıdır.

Eğitsel video ders materyalleri hazırlanırken kullanılan programlar nelerdir? Bu programları kullanabilmek için özel bir eğitim gerekli midir?

- A Görüşmecisi ve B Görüşmecisi: Bu yazllımlar (software) değişik firmalarda değişik isimlerde bulunan, Video Edit programlarıdır ve sürekli gelişim göstermektedirler. Mutlaka özel olarak çalışılmalıdır. Şeklinde ifade etmişlerdir.

- C Görüşmecisi: Video kamera dışında, Flash, Movie-Maker gibi programlar kullanılır. Flash Programı için ciddi bir eğitim gereklidir. Movie-Maker için de bir tanıtım ve temel bazı beceriler için (video alma, ekleme, silme, kaydetme) bir gösteren ve yaptıran etkinliği gereklidir. Şeklinde ifade etmiştir.

- D Görüşmecisi ve E Görüşmecisi: Senaryo yazımı için metin, tablo ve sekil programları, grafik-animasyon tasarımı için vektörel (çizim), 2 boyutlu 3 boyutlu görsel tasarım, canlandırma ve fotoğraf işleme programları, video için kurgu, montaj, canlandırma, efekt ve izleme programları, yazılım için kodlama, tasarlama, dönüştürme programları ve bunların yanında destek amaçlı çok çeşitıi yazılım ve donanımlar kullanılmaktadır.

Bu programları kullanmak ayrıca etkili ve yeterli tasarımlar hazırlayabilmek için uzmanlık gerekmektedir. Bunun içinde bu alanda eğitim veren kurum ya da hocalardan eğitim almalı, belli 
bir iş tecrübesine sahip olmalı ve mesleki güncel bilgileri, olayları takip etmelidir. Şeklinde ifade etmişlerdir.

- F Görüşmecisi: Windows Movie Maker ve Camtasia studio programları ve diğer programlar kullanılır. Bu programları kullanabilmek için herhangi bir eğitime ihtiyaç yoktur. Şeklinde ifade etmiştir.

Elde edilen verilere göre, A, B, C, D ve E görüşmecileri eğitsel video ders materyali hazırlamak için özel bir eğitimin gerekli olduğunu söylemişlerdir. Kullanılan programlar bir uzman eşliğinde veya bu alanın öğretim üyesinden alınan eğitim ışığında gerçekleştirilir. Flash Animasyon, Video Edit, MovieMaker diye bilinen video destekli eğitim için kullanılan programlar en yaygın ve kullanışlı olanlarıdır. Tabii bu programlar sürekli gelişim göstermektedir; teknolojinin de gelişimiyle. Bu programların özelliklerini öğrendikten sonra eğitimini doğru alan kişi kendi başına bu programları kullanabilir. Ancak, F görüşmecisi diğer görüşmecilerden farklı olarak Camtasia Studio programı için özel bir eğitime gerek duyulmadığını dile getirmiştir.

Eğitsel video ders materyalleri hangi eğitim türlerinde kullanılabilir?

- A ve B Görüşmecileri: Her tür eğitim ortamı için son derece başarılı bir tekniktir. (Örgün, Yaygın, Mesleki vs.). Şeklinde ifade etmiştir.

- C Görüşmecisi: Eğitsel videolar, her alanda ve eğitimin her kademesinde (Ana okul, Yüksek Öğrenim, Uzaktan Eğitim, Sanat Eğitimi, Müzik Eğitimi) kullanılabilir. Şeklinde ifade etmiştir.

- D Görüşmecisi ve E Görüşmecisi: Örgün, yaygın ve mesleki eğitim alanlarında kullanılabilir. Ağırlıklı olarak açık öğretim gibi uzaktan eğitim alanlarında kullanılmaktadır. Ayrıca üstün yetenekli ya da zihinsel engelli gibi özel eğitim alanlarında da kullanılmaktadır. Şeklinde ifade etmiştir.

- F Görüşmecisi: Eğitsel videolar; Kavram öğretiminde ve Beceri öğretiminde kullanılabilir. Bunlara ek olarak İş eğitiminde kullanıma da uygundur. Şeklinde ifade etmiştir.

Elde edilen verilere göre, eğitsel video ders materyalleri, eğitimin her alanında ve eğitimin her kademesinde kullanılır. Kavram öğretiminde, beceri öğretiminde ve iş eğitiminde de sıklıkla kullanılır. Örgün, yaygın ve mesleki eğitim alanlarında da fazlasıyla kullanılmaktadır. Ağırlıkıı olarak, özel eğitim, uzaktan eğitim ve açık öğretimde yaygın bir şekilde kulıanılmaktadır. Açık Öğretimde, uzaktan eğitim sistemiyle öğrenciler çalıştıkları için video destekli eğitim ihtiyacı onlarda daha fazla yer almaktadır. Kalıcı öğrenimi sağladığı ve her açıdan öğrenciye yardımcı kaynak olduğu için eğitim alanlarının genelinde kullanılmaktadır.

Eğitsel video ders materyali hazırlamanın maddi boyutu nedir?

- A Görüşmecisi ve B Görüşmecisi: Sahip olunan teknik donanıma bağlıdır ve piyasa şartlarına bağlı olduğundan net bir bedel söylemek pek mümkün değildir. Şeklinde ifade etmiştir.

- C Görüşmecisi: Digital Video Kamera (750-1000 TL) Adobe Flash ya da Movie-Maker (Bilgisayarlarda ücretsiz olarak geliyor) programları gereklidir. Adobe Flash Programı Movie-Maker Programına göre biraz daha pahalıdır; akademik sürümü (5000 TL) civarındadır. Movie-Maker birçok bilgisayarda ücretsiz olarak yüklü geliyor.

Digital Video ve Movie-Maker programlarını ve kaydedilecek CD'yi dikkate alırsak (750-1000 TL) arasında bir masraf ortaya çıkar. 
Elimizde bu programlar mevcut ise; o zaman çok düşük ya da hiç masrafsız olur." Şeklinde ifade etmiştir.

- D Görüşmecisi ve E Görüşmecisi: Maddi boyutların hesaplanmasında, sektörün durumu, ülkemizin sosyo ekonomik gelişmeleri, arz talep vb. konulara göre artı-eksi değişkenler bulunmaktadır. Ancak standart bir ücretlendirme için alan uzmanlarının emek-zaman-maliyet hesaplarını mevcut koşullara göre ortalama değerlerde tebliğ eden meslek birlikleri-odalardernekler bulunmaktadır. Bu kuruluşlardan güncel bilgilere erişilebilir.

Kendi deneyimlerimizden yola çıkarak cevap verecek olursak 20132014 yılı ortalama ücretlendirmeleri için örneğin 10 dakikalık bir ders materyalinde; Metin yazarı: (300-400TL), Akademisyen danışman; (300-400TL), Grafik animasyon: (500-2000TL), Stüdyokurgu-montaj: (1000-2000TL) aralığında bir maliyetle hazırlanmaktadır.

Bir şirkete bağlı olmadan freelance (serbest çalışan) diye tabir edilen alan uzmanlarının ücretlendirmelerinin daha ucuz maliyetlerde hazırlandığı da bilinmektedir. Ancak bu çalışma tarzı, işi resimlendirememe, teknik destek ya da geri dönüş için muhatabı bulamama, çıkan işin kalitesinin düşük olması gibi riskleri de barındırmaktadır. Bu durum tabii ki tam tersi de olabilir. Şeklinde ifade etmiştir.

- F Görüşmecisi: Çok kaliteli (teknik açıdan) videolar gerekli ise, maliyet yüksek olur. Büyük bir ekibe ihtiyaç duyulabilir. Şeklinde ifade etmiştir.

Elde edilen verilere göre, Eğitsel video ders materyali hazırlamanın maddi boyutu fazladır. C, D, E ve F görüşmecileri, bu video destekli eğitim için her alanda çalışanlara maddi açıdan bir bedel biçerken A ve B görüşmecileri, sahip olunan teknik donanımı içerdiği ve piyasa şartlarına bağlı olduğu için net bir bedel söylemenin mümkün olamadığını dile getirmiştir. Tabii bazen bu programlar bir maddi bedel ödemeden de bilgisayarlarda yüklü bir şekilde karşımıza çıkabiliyor, ama bilgisayarda olmadığını varsayarsak o zaman genel bir kanı ile ortaya çıkan maddi boyut (300-2000TL) civarında seyrini göstermektedir. Her alanın uzmanına ayrı bir ücretlendirilme yapılmaktadır. 2013-2014 yılları arasına bakıldığı şu zamanda genel ücretlendirme profili (300-2000TL) şeklinde görülmektedir. "Video modelli öğretimin avantajları ve dezavantajları nelerdir"?

- A Görüşmecisi ve B Görüşmecisi: Video izleme tekniği ile görüntü üzerinde istenilen komutlar tekrar tekrar verilebilir. İyi hazırlanmış ve kurgulanmış videolar görüntü ve efekt zenginliği ile çok detaylı bilgiler verebilir. Bireyselliği desteklerken sosyalliği geriletir. Kalitesiz videolarda başarı elde edilemez. Şeklinde ifade etmiştir.

- C Görüşmecisi: Öğrenme-Öğretme etkinliklerini aldıkça somutlaştırması en büyük avantajı. Tek dezavantajı çok kullanıldığında yüz-yüze etkileşimi sınırlandırmaktadır. Şeklinde ifade etmiştir.

- D Görüşmecisi ve E Görüşmecisi:

Avantajları:

o Zaman, mekân sınırlaması olmadan öğrenme (Örn: Yolculukta, tatilde, gece evde vs.)

- Tekrar etme, pekiştirme, hafızaya yerleştirme

- Paylaşıma açma

- Alternatif, farklı kaynaklara erişim şansını bulma 
Tecimer, G. ve Akgül Barış, D. , Fine Arts (NWSAFA), D0220, 2018; 13(4): 117-132.

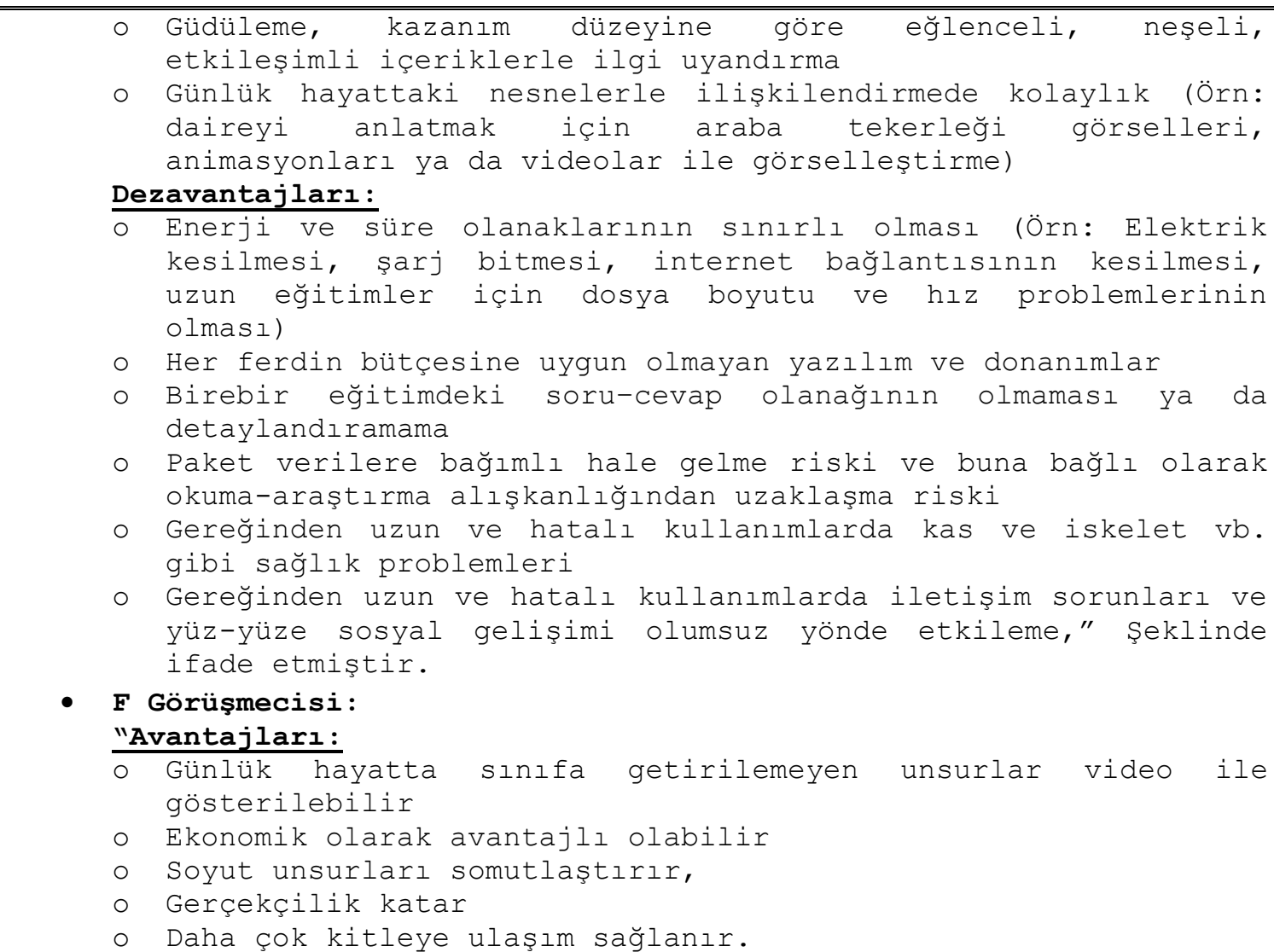

\section{Dezavantajları:}

o Öğretimsel açıdan zayıf olabilir

- Uzun süreli videolar öğrencinin motivasyon kaybına neden olabilir

- Yüksek teknik özellikli videolar için büyük bir ekibe ihtiyaç duyulabilir." Şeklinde ifade etmiştir.

Elde edilen verilere göre, A, B, C, D ve E görüşmecileri ortak olarak dezavantajları bölümüne bireysel anlamda kişileri geliştirirken, sosyallik anlamında etkileşimi ve iletişimi gerilettiği düşüncesini ele almışlardır. Onların düşüncelerinden farklı olarak F görüşmecisi, öğretim açısından zayıf olabileceğini düşünmüştür. Ayrıca, uzun süreli videoların öğrenciler üzerinde motivasyon kaybına sebep olabileceğini dile getirmiştir. D ve E görüşmecileri buna ek olarak, enerji ve süre olanaklarının sınırlı olmasını ele almış, her birey için uygun ve ekonomik bir bütçeye uygun olmamasını eleştirmiş, yüz-yüze öğrenim tekniğinin burada olmamasından bahsetmiş ve fazla karşısında oturulup, vakit geçirilirse sağlık sorunlarının baş göstereceğini söylemiştir. Avantajlarını ele alırsak, A, B, C ve F görüşmecileri, öğrenme-öğretme sürecinde somutlaştırılarak bilginin verilmesinin video destekli ders öğretiminde avantaj olduğunu göstermiştir. Buna ek olarak F görüşmecisi, günlük hayatta sınıfa getirilemeyen unsurların video destekli öğretim ile gösterilebileceğinden bahsetmiştir ve daha çok kitleye ulaşımın sağlanmasının kolaylığını dile getirmiştir. D ve E görüşmecileri; A, B ve C görüşmecilerinden farklı olarak, zaman ve mekân sınırlaması olmadan öğrenimin kolaylığından, tekrar etme ve pekiştirme gibi olanakların olmasından ve eğlenceli, farklı ilgi uyandıran yöntemlerle video destekli ders öğretiminin yararlı olmasından bahsetmiştir. 
6.3. Üçüncü Alt Probleme Ait Bulgular ve Yorumları (Findings and Comments of Third Sub-Problem)

"Uzman görüşleri doğrultusunda İlkokullarda Blok flüt eğitimine yönelik eğitsel video ders materyalin oluşturulması nasıl gerçekleşmektedir?" Yapılan Literatür taraması ve uzman görüşlerinden elde edilen veriler doğrultusunda materyalin oluşturma aşaması aşağıdaki gibi gerçekleştirilmiştir.

- Konunun Belirlenmesi: "Blok Flüt Öğretimi İçin Video Ders

Materyali Planının oluşturulması"

- Blok flütün masallaştırılarak tanıtımı ve konuya giriş (1. Video)

- Blok flütün çizgi karakterlerle, tanıtımının pekiştirilmesi (2. Video)

\section{Ana Kazanım Temaları:}

İlkokul Müzik Öğretim Programı, 4. Sınıf bilişsel alanı içindeki "Blok Flütün yapısı ve Blok Flüt de Temiz Ses Üretimi" ana kazanımları esas alınmıstır.

- Blok flütün yapısı tanır

- Sınıf çalgısı olarak blok flütün nasıl kullanılması gerektiğini bilir

- Blok flütten güzel ve temiz ses üretimi için gerekli özellikleri bilir

- Blok flüt ailesini tanır.

- Çalışma Ekibinin Oluşturulması: Araştırmacılar tarafından blok flüt eğitimi alanında uzman 2 akademisyen, 1 Türkçe bölümü Öğretim Görevlisi, 1 MEB Türk Dili Edebiyatı Öğretmeni, 2 sınıf öğretmenil TRT Çocuk Animasyon Bölümü Grafik Tasarım Uzmanı, Eğitim Teknolojileri Genel Müdürlüğü EBA (Eğitim Bilişim Ağı) da görevli 2 uzmandan oluşan gönüllü bir ekip oluşturulmuştur.

- Senaryo: Video 1 hazırlanırken uzman görüşleri çerçevesinde bir masal senaryosu oluşturulmuştur (Ek-1).

Video 2 Blok flütün kendini tanıtması (Ek-2).

Videolaştırmada Flas Animasyon Programı kullanılmış, Her iki konunun videolaştırılma aşamasında da TRT Çocuk Animasyon Bölümünü Oluşturan Ekiple ortak bir çalışma sürdürülmüştür.

- Hazırlanan senaryolara yönelik grafik tasarım ve animasyon çizimleri yapılmıştır.

Bu çizimler sırasıyla;

Karakterlerin oluşturulması, hikayenin geçtiği mekanların tasarlanması, konuşma iç ve dış seslerinin, efektlerin kayıt edilmesi

- Storyboard (hikaye tahtası) hazırlanması (hikayenin geçtiği planın kă̆ıt üzerinde gösterilmesi)

- Mekan ve karakter tasarımlarının hangi programlarla yapılacağına karar verilerek uygulanması

- Alan uzmanları ve akademik danışmanlar eşliğinde gerekli düzenlemeler yapıldıktan sonra videoların kurgu ve montajı yapılmıștır. Video dijital medyaya uyarlanacak formatlarda kaydedilmistir. Yazılımc tarafından dijital medyada izlenilebilecek şekilde kodlanarak yayına verilmiştir.

\section{SONUÇ VE TARTIŞMA (CONCLUSION AND DISCUSSION)}

İlk ve ortaokullarda Blok Flüt Eğitimi için hem sınıf öğretmenlerinin hem de müzik öğretmenlerinin kullanabileceği bir video ders materyali oluşturmanın amaçlandığı ve bu ders materyali oluştururken geçilen aşamaların ortaya koyulduğu bu araştırmada, elde edilen verilerden video ders materyali oluşturma aşamaları aşağıdaki gibidir. 
- Konu belirlenir

- Metin yazarı, akademisyen, alan uzmanı ile birlikte öğretim süreçleri tasarımı için bir ekip oluşturulur. Bu ekip ders materyalleri için uygun olan süre, metot, teknik, öğrenim içerik ve yapım stratejilerini belirler.

- Belirlenen süre, kazanım ve metotlara uygun olacak şekilde senaryo yazılır.

- Onaylanan ve tashih edilen senaryoya bağlı olarak grafik tasarım ve animasyon çizimleri yapılır.

- Storyboard hazırlanır

- Stüdyo ya da dış ortamda video çekimi yapılır.

- Çekimi bilgisayar ortamına aktarılır

- Uygun bir Video-Edit (Movie-Maker, vs.) ile çekimi edit edilir, (düzeltmelerde, eklemelerde bulunmak) yazı ve jenerik eklenir,

- Video kaydedilir.

- Alan uzmanları ve akademik danışmanlar eşliğinde ham materyali gözleyerek eksikler ya da eklenilmesi gerekenler belirlenir.

- Gerekli düzenlemeler yapıldıktan sonra videonun kurgu ve montajı yapılır.

- Dijital medyaya uyarlanacak formata getirilir.

- Yazılımci tarafindan dijital medya mecralarında izlenebilecek şekilde kodlanarak yayına verilir.

Kaya (2005)'nın "Öğretim Teknolojileri ve Materyal Geliştirme" adlı kitabında da video ders materyali oluşturma aşamaları, araştırma sonuçlarındaki sıralama ile benzerlik göstermektedir. Eğitsel video ders materyali hazırlarken hedeflenen kitle büyük önem taşır. Video ders materyalleri öğrencilerin ilgisine göre soyut veya somut çekimlerle desteklenmeli, Ayrıca hedef kitlenin genel özellikleri, motivasyonları, hazır bulunuşlukları dikkate alınmalıdır. Eğitsel video ders materyali hazırlarken alanında uzman kişilerin yer aldığı kapsamlı bir ekiple çalışmak gerekmektedir. Flash Animasyon, Video Edit, Movie-Maker diye bilinen programlar video ders materyali hazırlarken kullanılan en yaygın ve kullanışlı programlar olarak belirtilmiştir. Eğitsel video ders materyalleri, eğitimin her alanında ve eğitimin her kademesinde kullanılabilir.

Ağırlıklı olarak, özel eğitim, uzaktan eğitim ve açık öğretimde yaygın bir şekilde kullanılmaktadır. Diğer eğitim materyallerine oranla video ders materyali hazırlamanın maddi boyutu fazladır. Ama bunun yanı sıra bireysel ve sınıf içi motivasyonu arttırdığı, öğrenmeyi kalıcılaştırdığı, tekrarlama ve pekiştirmeye olanak sağladığı, öğrenmeyi eğlenceli hale getirdiği ve daha çok kişiye ulaşma imkânı sağladığı söylenebilir. Bunun yanı sıra ders materyalleri sadece tek başına bir öğretim aracı değildir. Yüz yüze eğitime destek kaynak olarak kullanılmalıdır. Orhan ve Akkoyunlu, (1999) ve Dinçer (2006)'de makalelerinde, Eğitsel Video Materyallerinin Yararları ve Sınırlılıkları ile ilgili aynı ifadeleri işaret etmektedirler. Bütün bu bilgilerin ışığı altında ilkokullarda Blok flüt eğitiminde kullanılmak üzere örnek bir eğitsel video ders videosu hazırlanmıştır. Videoda ilk ve ortaokul 4. ve 5. Sınıf müzik öğretim programının (2005) Blok flüt eğitimine yönelik ana kazanım temaları esas alınmış, bu temaların öğretimine ilişkin özgün bir senaryo oluşturulmuştur (Ek1-Ek2). Senaryolara yönelik grafik tasarım ve animasyon çizimleri yapılmıştır. Savaş ve Arıcı (2009)'a göre; konu anlatımını güçlendirmek amacı ile çeşitli flash animasyonlar kullanılmıştır. Böylece öğrencinin hazırlanan senaryolarının içerisinde dolaşarak öğretilmesi hedeflenen bilgi, kavram ve olguları keşfetmesi hedeflenmektedir. 


\section{8. ÖNERILER (SUGGESTIONS)}

- Eğitsel video ders materyalleri, eğitimin her alanında ve eğitimin her kademesinde kullanılmalıdır.

- Eğitsel video ders materyali hazırlarken alanında uzman kişilerin yer aldığı kapsamlı bir ekiple çalışılmalıdır.

- Eğitsel video ders materyalleri öğrencilerin ilgisine göre soyut veya somut çekimlerle desteklenmeli, Ayrıca hedef kitlenin genel özellikleri, motivasyonları, hazır bulunuşlukları dikkate alınmalıdır.

- Araştırma sonuçları çerçevesinde farklı çalgılar için de eğitsel video ders materyalleri hazırlamak müzik eğitimini çocuklar için zevkli hale getirebilmek adına yararlı olacaktır.

\section{NOT (NOTICE)}

Bu makale Kırıkkale Üniversitesi Güzel Sanatlar Fakültesi tarafından düzenlenen "I. Uluslararası Müzik Araştırmaları Öğrenci Kongresi"nde 28-30 Mart 2018 sözlü bildiri olarak sunulmuştur.

\section{KAYNAKÇA (REFERENCE)}

- Akgül Barış, D., (2007). Okul Müzik Eğitiminde Çalgı Eğitimi Uygulamaları. Bolu: BAİBÜ Eğitim Fakültesi Sosyal Bilimler Enstitüsü Dergisi. $15(2): 1-12$.

- Alkan, C., (1997). Eğitim Teknolojisi. Ankara: Anı Yayıncılık.

- Dinçer, S., (2006). Bilgisayar Destekli Eğitim ve Uzaktan Eğitime Genel Bir Bakış. Çukurova Üniversitesi Eğitim Fakültesi BÖTE Anabilim Dalı, Adana.

- Ergin, A., (1995). Öğretim Teknolojisi. (1. Baskı). Ankara: Pegem Personel Eğitim Merkezi Yayını.

- Ertürk, S., (1972). Eğitimde Program Geliştirme. Ankara: Yelkentepe Yayınları.

- Kaya, Z., (2005). Öğretim Teknolojileri ve Materyal Geliştirme. Ankara: Pegem Yayıncılık.

- Orhan, F. ve Akkoyunlu, B., (1999). Uzaktan Egitim Yaklaşımında Temel Egitim İ. Kademe Ögretmenleri'nin Video Destekli Hizmet içi Egitimi. Hacettepe Üniversitesi Eğitim Fakültesi Dergisi 16$17: 134-141$.

- Savaş, S. ve Arıcı, N., (2009). Web Tabanlı Uzaktan Eğitimde İki Farklı Öğretim Modelinin Öğrenci Başarısı Üzerindeki Etkilerinin İncelenmesi. 5. Uluslararası İleri Teknolojiler Sempozyumu. Bildiri, (IATS) (13-15 Mayıs, ss:1-8), Karabük, Türkiye.

- Tecimer, B., (2006). Internet ve Yaşam Boyu Müzik Eğitimi. www.muzikegitimcileri.net (Müzed, Kış-15,8-9), Tarih: 2015.05.15.

- Tekin, C., (1988). Çağdaş Bir Eğitim ve İletişim Aracı Video Araştırma-Kuram-Uygulama. Eskişehir: Anadolu Üniversitesi Eğitim Teknolojisi ve Yaygın Eğitim Vakfı Eğitim Araştırma ve Bilimsel Yayınlar Dizisi.

- Yıldırım, A. ve Şimşek, H., (2013). Sosyal Bilimlerde Nitel Araştırma Yöntemleri. (Geliştirilmiş 9. Baskı). Ankara: Seçkin Yayıncılık.

\section{Internet Kaynağı}

- http://botemateryal.blogspot.com.tr/p/blog-page 2.html)

- http://botemateryal.blogspot.com.tr/p/egitim-ogretime-sagladıg yararlar_2.html)

- http://www.researchgate.net/publication/298192658_bılgısayar desteklı_egıtım_ve_uzaktan_egıtıme_genel_bır_bakıs) 


\section{EKLER}

Ek-1: Selin'in Rüyası

Selin ilk kez gördüğü bu şeye hayretle bakıyordu. İlk önce ne olduğunu anlayamadığı şey ince, uzun, delikleri olan ve kırmızı renkte bir şeydi. Selin sessizce onun yanına yaklaştı, kendi kendine konuşmaya başladı. Ne olabilir ki? Acaba bu ne işe yarıyor?, Sanki ben bunu daha önceden bir yerde gördüm. Merhaba! Selin irkildi sesin nerden geldiğini anlayamamıştı. Etrafına bakınırken beni mi merak ediyorsun? diyen aynı sesi tekrar duydu. Kulaklarına inanamadı yoksa bu ses o şeye mi aitti. Dikkatlice ona bakarken beni mi merak ettin? dedi. İnce, uzun, delikli alet... Sen konuşuyor musun? dedi, hayretle. Evet! inanamıyorum çok güzel! Sen nesin? Ben bir müzik aletiyim. İnsanların bazen duygularını benimle anlatmalarını sağlarım. Adın ne? Ben Blok flütüm. Her çocuğun hayatında mutlaka yer alırım. Onun için en çok sevilen çalgıyım. Beni çalmak çok kolay, çekinme alsana eline. Selin yine de çekinerek Blok flütü eline alır. Dudaklarına götürür, üfler. İlk üfleyişte bozuk ve gürültülü bir ses çıkarır. Hani senden güzel ses çıkardı? Kızar ve bırakmak ister. Beni bırakma! Bir daha dene ama bu sefer çok fazla üfleme, ayrıca gördüğün deliklerim var ya onları da parmaklarınla kapatarak çalmayı dene. Selin denileni yapar ve Blok flütü tekrar üfler. Selin, Selin! Kızım haydi kalkmalısın okul vakti; diyen annesinin sesiyle uyanan Selin, günaydın annecim sana bir şey anlatmam gerek. Rüyamda Blok flüt çalıyordum. Anne lütfen bana Blok flüt alalım, Öğretmenim de öğretsin bana, diyerek heyecanla yatağından kalkar ve her zamankinden daha keyifle bugün okula gider.

Ek-2: Blok Flütün Kendini Tanıtması

Blok Flütün Kendini Tanıtması

Benim hakkımda birçok şeyi öğrenmeye başladınız; beni biraz daha yakından tanımaya ne dersiniz?

- Okullarda en çok kullanılan çalgı benimdir. Ayrıca Anadolu'da çalınan dilli kavalların benzeriyimdir. Beni Yan Flüt' ten ayırt etmek için bana düz flütte denir.

- Benim hangi malzemeden yapıldığımı biliyor muydunuz? Ben ağaç üflemeli bir çalgıyım. Genellikle plastik veya ağaçtan yapılırım. Eskiden de fildişinden yapılırdım.

- Peki, benim 8 deliği olan bir çalgı olduğumu biliyor muydunuz? 7 si üstte, 1 i alttadır.

- Benim de sizin gibi ailem var. Onlarla tanışmak ister misiniz? Biz dört kişilik bir aileyiz. Soprano benim, Alto annem, Tenor babam, Bas ta dedemdir. Beni yani Soprano Blok Flütü okullarda çalmaktasınız. Bana Soprano Do Blok Flütte denir; çünkü en kalın sesim "Do" dur.

- Günümüzde beni çalıyorsunuz, acaba geçmişte de ben çalınmakta mıydım hiç merak ettiniz mi?

Evet, çalınıyordum. Yüzyıllar öncesinden bilinmekte ve çalınmaktaydım. Özellikle önemli besteciler eserlerinde bana fazlasıyla yer vermekteydiler.

- Peki, ben müzik eğitiminde ve okullarda neden bu kadar çok çalınıyorum ve seviliyorum hiç düşündünüz mü?

Çünkü; beni öğrenmek kolaydır. Sizlerin beni çalabilmesi için uygun bir çalgıyım. Çok kolaydır beni taşımak. Hafif olduğum için beni çalanı yormam. Pahalı da değilimdir. Plastik olduğumdan fazla bakımda gerektirmem. Yalnız çalınan ve toplu çalınan müziklerde de uygunumdur.

- Kaç parçadan oluştuğumu biliyor muydunuz?

Üç parçadan oluşurum. Birinci Bölümüm Baş kısmımdır. İkinci Bölümüm Gövde kısmımdır. Üçüncü Bölümüm de Uç kısmımdır. 
Tecimer, G. ve Akgül Barış, D. ,

Fine Arts (NWSAFA), D0220, 2018; 13(4): 117-132.

- Baş kısmımda, Hava tüneli, Blok yani dil ve düdük bulunmaktadır. Benden çıkan ses burada üretilir.

- Gövde Kısmımda, baş kısmımın ve uç kısmımın arasında kalan bölümümdür. Önde altı arkada bir delik vardır. Baş kısmımda oluşan ses, gövdemdeki deliklerin kullanılmasıyla incelikalınlı seslere dönüşür.

- Son olarak Uç kısmımda, bir delik bulunur. Üflediğiniz nefes gövde kısmımdan uç kısmıma iletilir. 